\title{
PENERAPAN DIVERSI TERHADAP ANAK YANG BERHADAPAN DENGAN HUKUM DIHUBUNGKAN DENGAN PEDOMAN PELAKSANAAN DIVERSI DALAM SISTEM PERADILAN PIDANA ANAK
}

\author{
Yusuf Luqita Danawiharja \\ Alumni Program Studi Magister Ilmu Hukum \\ Pascasarjana Universitas Islam Bandung \\ Email : Yusufluqita73@yahoo.com
}

\begin{abstract}
Abstrak : Penanganan anak yang berkonflik dengan hukum seringkali disamakan dengan penanganan orang dewasa yang melakukan tindak pidana. Dalam penelitian ini penulis menggunakan metode pendekatan yuridis normatif. Spesifikasi Penelitian, penelitian ini bersifat deksriptif analitis. Jenis data, yaitu data sekunder. Pengumpulan data dilakukan melalui studi kepustakaan (Library Research). Data yang diperoleh dianalisis dengan menggunakan metode normatif kualitatif. Hasil dari penelitian ini ialah. Pertama, Penerapan diversi terhadap anak baik pada tingkat Penyidikan, Penuntutan dan Peradilan dapat dilaksanakan selama memenuhi persyaratan, sebagaimana diatus dalam Pasal 7 angka 2 Undang-Undang Sistem Peradilan Pidana Anak dan sesuai dengan Perma Nomor 4 Tahun 2014 tentang Pedoman Pelaksanaan Diversi Dalam Sistem Peradilan Pidana Anak. Kedua, Kendala Implementasi Diversi dalam penanganan tindak pidana yang dilakukan oleh anak, Pemahaman masyarakat dan aparat penegak hukum lainnya terhadap Diversi masihlah kurang.
\end{abstract}

Kata Kunci: Anak Berhadapan Dengan Hukum, Diversi, Peradilan Pidana.

Abstract: Handling children conflicting with the law is frequently the same as handling adults committing a crime. Juridically in Indonesia, legal protection for children can be found in various laws and regulations. The regulation aims at creating welfare, protecting children's rights and proving justice for children. The objective of this study is to understand the diversion implementation toward children based on the law of the Supreme Court Regulation Number 4 Year 2014 concerning Diversion Implementation Guidelines in the Juvenile Criminal Justice System and to comprehend the constraints of the diversion implementation to children conflicting with the law. This study used a normative juridical approach using analytical descriptive in nature. Data collection was conducted through library research analyzed using qualitative normative method. The result shows that the diversion implementation toward children at the level of Investigation, Prosecution, and Justice can be conducted as long as it meets the requirements, as stipulated in Article 7 point 2 of the Juvenile Criminal Justice System Law. Additionally, Supreme Court Regulation Number 4 Year 2014 states that diversion can be conducted in the case of a criminal act committed under the 
penalty of imprisonment for less than 7 years does not constitute a repetition of the criminal act. The obstacle is that the victims assume that their rights are not protected because the suspect is given privileges in the legal process. Meanwhile, the victims and their family thought that law implementation is more in favor of the suspect.

Keywords: Children Facing the Law, Diversion, Criminal Justice.

\section{A. PENDAHULUAN}

\section{Latar Belakang}

Anak-anak adalah bagian dari generasi muda dan merupakan salah satu sumber daya manusia yang memainkan peran strategis di masa depan perjuangan bangsa, potensi dan cita-citanya yang berkelanjutan. Selain itu, ia memiliki fitur khusus yang menjamin keberlanjutan bangsa dan negara di masa depan. Setiap anak akan dapat mengambil tanggung jawab. Oleh karena itu, anak-anak harus memiliki kesempatan seluasluasnya untuk tumbuh dan berkembang secara optimal, baik secara fisik maupun mental, serta sosial dan moral. Perlindungan juga harus diberikan untuk meningkatkan kesejahteraan anak-anak dengan memastikan bahwa semua hak dihormati dan diakui tanpa diskriminasi. ((M. R. Ghoni, and P. Pujiyono, Perlindungan Hukum
Terhadap Anak yang Berhadapan dengan Hukum Melalui Implementasi Diversi di Indonesia, Jurnal Pembangunan Hukum Indonesia, Vol. 2, No. 3, pp. 331-342, Aug. 2020).

Diversi bagi pelaku anak adalah untuk menyediakan alternatif yang lebih baik dibanding dengan prosedur resmi beracara di pengadilan Jaksa penuntut umum merupakan salah satu aparat penegak hukum yang melaksanakan Diversi, selain polisi dan hakim. (Setya Wahyudi, 2011:53)

Mayoritas anak yang berhadapan dengan hukum, terutama yang dibawa ke sistem peradilan pidana, hakim menjatuhkan pidana tetap perampasan kemerdekaan. Efek negatif disebabkan oleh adanya proses pengadilan pidana yaitu efek negatif sebelum pemeriksaan perkara, ini timbul karena terdapat sumbersumber tekanan seperti: pertanyaan yang tidak simpatik; anak harus 
menceritakan kembali peristiwa yang tidak menyenangkan; menunggu persidangan; dan pemisahan dengan keluarga. Efek negatif ketika proses persidangan terhadap anak dikarenakan adanya tata ruang pengadilan; berhadapan dengan korban, dan para saksi; berbicara dihadapan para petugas pengadilan. Efek negatif setelah persidangan terhadap anak, hal ini disebabkan dengan adanya putusan hakim. (Setya Wahyudi, 2011:4).

Upaya menghindari efek negatif proses peradilan pidana yaitu dengan memberikan kewenangan kepada aparat penegak hukum, salah satunya jaksa penuntut umum untuk mengambil tindakan-tindakan kebijakan dalam menangani atau menyelesaikan masalah pelanggar anak dengan tidak mengambil jalan formal, antara lain menghentikan atau tidak meneruskan atau melepaskan dari proses pengadilan atau mengembalikan atau menyerahkan kepada masyarakat dan bentukbentuk kegiatan pelayanan sosial lainnya, tindakan ini disebut Diversi, dengan adanya tindakan Diversi ini, maka diharapkan akan mengurangi dampak negatif akibat keterlibatan anak dalam proses pengadilan tersebut.

Tahun 2016 dinilai merupakan tahun dengan jumlah anak terbanyak yang berhadapan dengan hukum. Namun dengan mempertimbangkan banyak hal, beberapa anak-anak yang terlibat pelanggaran hukum mendapat diversi atau pengalihan penahanan dari pihak kepolisian. Diversi diberikan dengan mempertimbangkan anak-anak yang dinilai masih panjang masa depannya, sehingga anak yang dikenakan diversi ini tidak ditahan. Diversi sendiri hanya diberikan untuk anak yang berhadapan dengan hukum, dengan ancaman di bawah tujuh tahun penjara.

\begin{tabular}{|l|l|}
\hline Tahun & Jumlah \\
\hline 2015 & 21 \\
\hline 2016 & 13 \\
\hline 2017 & - \\
\hline 2018 & 1 \\
\hline 2018 & \\
\hline
\end{tabular}

1. Jumlah kasus Diversi Anak Yang Berhadapan Dengan Hukum di 
Kabupaten Cirebon. (Data dari Satuan Reserse Kriminal Kabupaten Cirebon)

Usaha penanggulangan
kejahatan mengejawantah dalam
berbagai bentuk yaitu bentuk pertama
adalah bersifat represif yang
menggunakan sarana penal yang
sering disebut dengan sistem
peradilan pidana. Yang kedua usaha-
usaha tanpa sarana penal (prevention
without punishment), dan yang ketiga
menggunakan usaha-usaha
pembentukan opini masyarakat
tentang kejahatan dan sosialisasi
hukum melalui mass media secara
luas. (Dey Ravena dan Kristian,
2017:136)

Penerapan diversi tersebut dimaksudkan untuk mengurangi dampak negatif keterlibatan Anak dalam suatu proses peradilan. Peradilan Anak merupakan sistem peradilan yang bersifat restorative justice dengan mengutamakan kebutuhan dan kepentingan dimasa yang akan datang. Stigmatisasi Anak nakal seperti yang terjadi selama ini tidak akan memberikan peluang kepada Anak untuk mendapatkan ruang tumbuh kembang yang lebih baik. Begitu juga penanganan Anak dipenjara, jangan sampai menimbulkan trauma dan tidak ditahan bersama orang dewasa.

Berdasaran pikiran tersebut, maka lahirlah konsep diversion yang dalam istilah bahasa Indonesia disebut diversi atau pengalihan. Diversi dilakukan untuk menemukan suatu bentuk penyelesaian yang memberikan perlindungan terhadap Anak dengan mengedepankan prinsip the best interest of the child. Konsep diversi lahir didasarkan pada kenyataan bahwa proses peradilan pidana terhadap Anak pelaku tindak pidana melalui sistem peradilan pidana konvensional lebih banyak menimbulkan bahaya dari pada kebaikan. Dalam hal ini mekanisme peradilan akan memberikan stigma terhadap Anak atas tindakan yang dilakukannya sebagai Anak jahat, sehingga lebih baik untuk menghindarkan Anak dari sistem peradilan pidana konvensional ke mekanisme penyelesaian di luar 
sistem peradilan pidana. Nomor 4 Tahun 2014 Tentang Pertimbangan dilakukannya diversi Pedoman Pelaksanaan Diversi didasarkan pada alasan untuk Dalam Sistem Peradilan Pidana memberikan keadilan kepada Anak yang telah melakukan tindak pidana serta memberikan kesempatan pada Anak untuk memperbaiki dirinya.

\section{Identifikasi Masalah}

1. Bagaimana penerapan diversi terhadap anak yang berhadapan dengan hukum dihubungkan Peraturan Mahkamah Agung Nomor 4 Tahun 2014 Tentang Pedoman Pelaksanaan Diversi Dalam Sistem Peradilan Pidana Anak?

2. Bagaimana kendala penerapan diversi terhadap anak yang berhadapan dengan hukum Peraturan Mahkamah Agung Nomor 4 Tahun 2014 Tentang Pedoman Pelaksanaan Diversi Dalam Sistem Peradilan Pidana Anak?

\section{Tujuan Penelitian}

1. Untuk memahami penerapan diversi terhadap anak yang berhadapan dengan hukum Peraturan Mahkamah Agung Anak.

2. Untuk memahami kendala penerapan diversi terhadap anak yang berhadapan dengan hukum Peraturan Mahkamah Agung Nomor 4 Tahun 2014 Tentang Pedoman Pelaksanaan Diversi Dalam Sistem Peradilan Pidana Anak.

\section{B. PEMBAHASAN}

1. Penerapan diversi terhadap anak yang berhadapan dengan hukum dihubungkan Peraturan Mahkamah Agung Nomor 4 Tahun 2014 Tentang Pedoman Pelaksanaan Diversi Dalam Sistem Peradilan Pidana Anak

Perlindungan anak menurut Pasal 1 angka 2 Undang-Undang Nomor 23 Tahun 2002 tentang Perlindungan Anak (selanjutnya ditulis UUPA) adalah segala kegiatan untuk menjamin dan melindungi anak dan hak-haknya agar dapat hidup, tumbuh, berkembang, dan berpartisipasi, secara optimal sesuaidengan harkat dan martabat 
kemanusiaan, serta mendapat Sebagai ganti dari sanksi hukumnya, perlindungan dari kekerasan pelaku tindak pidana dapat menganti dandiskriminasi. dengan membayar ganti rugi, kerja

Dalam perlindungan terhadap sosial, atau tindakan-tindakan yang anak yang berhadapan dengan hukum, penyelesaiannya dapat masih dalam batas kewajaran yang diperintahkan oleh penegak hukum dilakukan dengan mengedepankan keadilan restoratif. Kaedilan restoratif berdasarkan Pasal 1 angka 6 UU SPPA adalah penyelesaian perkara tindak pidana dengan melibatkan pelaku, korban, keluarga pelaku/korban, dan pihak lain yang terkait untuk bersama-sama mencari penyelesaian yang adil dengan menekankan pemulihan kembali pada keadaan semula, dan bukan pembalasan.

Penyelesaian tindak pidana anak dengan cara diversi dan Keadilan restoratif, jelas bertentangan dengan asas legalitas dan asa kepastian hukum (rechtzakerheid). Sebeb, keadilan restoratif hasil akhirnya bukan pemidanaan atau hukuman penjara, tetapi, keadilan restoratif fokus pada perbaikan dan pemulihan keadaan korban pasca terjadinya suatu tindak pidana. terhadap: atau pengadilan.

Setelah disahkannya UU Nomor 11 tahun 2012, barulah ada landasan hukum yang jelas tentang pelaksanaan Diversi. Dalam aturan ini diatur pelaksanaan Diversi dapat dilakukan disemua tingkat proses peradilan dari penyidikan hingga perkara anak di pengadilan. (Pasal 7 ayat (1) UU No 11 Tahun 2012) Adapun tindak pidana yang dapat dilaksanakan Diversi adalah:

a. Diancam dengan pidana penjara di bawah 7 (tujuh) tahun; dan

b. Bukan merupakan pengulangan tindak pidana.

Adapun hasil dari pelaksanaan Diversi dibuat kesepakatan Diversi yang harus mendapat Persetujuan korban dan/atau keluarga Anak Korban serta kesediaan Anak dan keluarganya. Terdapat pengecualian 
a. Tindak pidana yang berupa 2. Apabila tersangka ditahan, hendaknya pelanggaran;

b. Tindak pidana ringan; disarankan supaya segera dibebaskan

c. Tindak pidana tanpa korban; atau melalui prosedur d. Nilai kerugian korban tidak lebih dari nilai upah minimum provinsi setempat.

Suatu terobosan hukum dilakukan oleh Jaksa Agung, yaitu dengan mengelurkan Surat Edaran Jaksa Agung RI Nomor: SE002/j.a/4/1989 Tentang Penuntutan Terhadap Anak. Pada surat edaran tersebut bagian penuntutan dinyatakan bahwa setelah usia tersangka dapat diketahui secara pasti berdasarkan bukti-bukti yang sah, maka:

1. Apabila tersangka berumur 10 tahun, maka jaksa peneliti (calon penuntut umum) melakukan pendekatan kepada penyidik untuk tidak melanjutkan penyidikan tetapi cukup memberikan bimbingan/penerangan secara bijaksana kepada tersangka maupun kepada orangtua/walinya sehingga perkaranya tidak perlu dikirimkan ke kejaksaan; penangguhan/pengalihan penahanan, sedangkan kalua masih dipandang perlu untuk melakukan penahanan, disarankan agar tempat penahanan pada rutan/lembaga tidak disatukan dengan tahanan dewasa. Surat edaran tersebut mencerminkan semangat perlindungan bagi anak dari dampak negatif sistem peradilan dengan cara menghentikan penuntutan dan memberikan bimbingan bagi anak dan orang tuanya.

Diversi dalam sistem peradilan pidana anak Pasal 1 angka 1 UU SPPA menyebutkan bahwa "Sistem Peradilan Pidana Anak adalah keseluruhan proses penyelesaian perkara Anak yang berhadapan dengan hukum, mulai tahap penyelidikan sampai dengan tahap pembimbingan setelah menjalani pidana". Menurut Peradilan anak bertujuan memberikan yang paling baik bagi anak, tanpamengorbankan kepentingan masyarakat dan tegaknya keadilan. Dalam UU SPPA, seorang 
anak yang melakukan suatu tindak pidana disebut anak yang berkonflik dengan hukum, Pasal 1 angka 3 UU SPPA menjelaskan bahwa "Anak yang Berkonflik dengan Hukum yang selanjutnya disebut Anak adalah anak yang telah berumur 12 (dua belas) tahun, tetapi belum berumur 18 (delapan belas) tahun yang diduga melakukan tindak pidana". Dalam UU SPPA tindak pidana yang dilakukan oleh anak, penyelesaiannya dapat dilakukan dengan cara diversi, atau pengalihan penyelesaian perkara di luar peradilan, hal ini sebagaimana diatur Pasal 1 angka 7 UU SPPA, yang menyatakan bahwa "Diversi adalah pengalihan penyelesaian perkara Anak dari proses peradilan pidana ke proses di luar peradilan pidana".

Implementasi dari ide diversi dalam penanganan tindak pidana yang dilakukan oleh anak yang berhadapan dengan hukum dengan mengedepankan peradilan restroatif (Restorative Justice).Dalam Sistem Peradilan Pidana Anak, lembagalembaga penegak hukum yang terkait dalam menangani tindak pidana anak dapat mengambil tindakan diversi, seperti Kepolisian, Kejaksaan dan Pengadilan, dengan syarat ancaman hukuman di bawah 7 (tujuh) tahun dan bukan tindak pidana pengulangan, sebagaimana di atur Pasal 7 angka 2 UU SPPA, yang menyatakan bahwa "Diversi sebagaimana dimaksud pada ayat (1) dilaksanakan dalam hal tindak pidana yang dilakukan:

a. Diancam dengan pidana penjara di bawah 7 (tujuh) tahun; dan

b. Bukan merupakan pengulangan tindak pidana.

Tujuan dari diversi sebagaimana di atur Pasal 6 UU SPPA, Diversi bertujuan:

a. Mencapai perdamaian antara korban dan anak;

b. Menyelesaikan perkara anak di luar proses peradilan;

c. Menghindarkan anak dari perampasan kemerdekaan;

d. Mendorong masyarakat untuk berpartisipasi; dan

e. Menanamkan rasa tanggung jawab kepada anak. 


\begin{abstract}
Perlindungan hukum bagi anak dapat dilakukan sebagai upaya perlindungan hukum terhadap berbagai kebebasan dan hak asasi anak. Perlindungan terhadap anak ini juga mencakup kepentingan yang berhubungan dengan kesejahteraan anak. Perlindungan anak-anak yang berhadapan dengan hukum $(\mathrm{ABH})$, merupakan tanggung jawab bersama aparat penegak hukum. Tidak hanya anak sebagai pelaku, namun mencakup juga anak yang sebagai korban dan saksi. Aparat penegak hukum yang terlibat dalam penanganan $\mathrm{ABH}$ agar tidak hanya mengacu pada Undang-undang Nomor 11 tahun 2012 tentang sistemsistem peradilan pidana anak atau peraturan perundang-undangan lainnya yang berkaitan dengan penanganan $\mathrm{ABH}$, namun lebih mengutamakan perdamaian daripada proses hukum formal yang mulai diberlakukan 2 tahun setelah UU SPPA diundangkan atau 1 agustus 2014 (Pasal 108 UU No. 11 tahun 2014).

Mahkamah Agung merespon undang-undang Sistem Peradilan Pidana Anak dengan sangat progresif. Ketua Mahkamah Agung RI Muhammad Hatta Ali menendatangani Peraturan Mahkamah Agung (PERMA) Nomor 4 tahun 2014 tentang pedoman pelaksanaan Diversi dalam sistem peradilan pidana anak bahkan sebelum peraturan pemerintah yang merupakan prosedur hukum yang masih sangat anyar dalam sistem dan pembaharuan hukum pidana di Indonesia. Disamping itu juga, PERMA ini memuat pegangan Hakim dalam penyelesaian pidana anak mengingat belum ada regulasi yang memuat hukum acara khusus diversi Sistem Peradilan Pidana Anak.

Menurut PERMA 4 tahun 2014 Musyawarah Diversi adalah musyawarah antara pihak yang melibatkan anak dan orang tua/wali, korban dan/atau orangtua/walinya, pembimbing kemasyarakatan, pekerja sosial profesional, perwakilan dan pihak-pihak yang terlibat lainnya untuk mencapai kesepakatan diversi
\end{abstract}


melalui pendekatan keadilan Kehadiran ketentuan Pasal 3 Perma restoratif.

Diversi menunjukkan bahwa proses

Berdasarkan penjelasan Perma peradilan pidana telah berjalan dan Diversi terhadap Pasal 7 ayat (2) UU dilaksanakan oleh penyidik dan SPPA tersebut, maka ancaman pidana di bawah 7 (tujuh) tahun yang penuntut umum, sebagai akibat tindakan yang dilakukan oleh anak mengacu kepada hukum pidana yang berkonflik dengan hukum yang mempunyai arah patokan diversi kepada jenis dan berat ringannya tindak pidana yang dilakukan. diancam dengan pidana di atas 7 tahun. Jika peraturan pelaksana dari Sedangkan prinsip hukum yang dianut oleh ketentuan Pasal 3 Perma, uang pengganti adalah ketentuan pidana yang memenuhi dan tidak memenuhi persyaratan diversi berdasarkan model dakwaan yang didakwakan penuntut umum kepada anak.

Berkaitan dengan diversi ini, melalui pemberlakukan Pasal 3 Perma Diversi, secara prinsip tidaklah selaras dengan tujuan pengupayaan diversi yang diatur dalam Pasal 6 UU SPPA. Pada butir b tujuan diversi, sebagaimana dijelaskan di atas, bahwa tujuan diversi adalah untuk menghindarkan anak dari proses peradilan dengan menyelesaikan perkara anak di luar proses peradilan. UU SPPA hanya mengacu kepada Perma Diversi, maka penerapan diversi terhadap tindak pidana yang ancaman pidananya di atas 7 tahun seperti tindak pidana narkotika, bukan hanya menimbulkan ketidakpastian hukum, tetapi juga telah bertentangan dengan tujuan diversi yang diamanatkan oleh UU SPPA.

Menurut Undang-Undang Nomor 35 Tahun 2014 tentang Perubahan Atas Undang-Undang Nomor 23 Tahun 2002 tentang Perlindungan Anak pasal 1 ayat (12) hak anak adalah bagian dari hak asasi manusia yang wajib dijamin, dilindungi, dan dipenuhi oleh Orang Tua, Keluarga, masyarakat, negara, pemerintah, dan pemerintah daerah. Terdapat empat prinsip utama yang 
terkandung di dalam Konvensi Hak Anak, prinsip-prinsip ini adalah yang kemudian diserap ke dalam UndangUndang Nomor 23 Tahun 2002 yang disebutkan secara ringkas pada pasal. Secara lebih rinci Prinsip-prinsip tersebut adalah: (Supriyadi W. Eddyono, 2005:2)

a. Prinsip non diskriminasi.

b. Prinsip yang terbaik bagi anak (best interest of the child).

c. Prinsip atas hak hidup, kelangsungan dan perkembangan (the rights to life, survival and development).

d. Prinsip penghargaan terhadap pendapat anak (respect for the views of the child).

Dalam sejarahnya instrument hukum yang melindungi hak-hak anak telah dimulai sejak tahun 1924, dimana pada tahun tersebut Deklarasi Hak Anak secara internasional diperkenalkan oleh liga bangsabangsa dengan nama Deklarasi Jenewa. Perkembangan penting dalam sejarah hak asasi manusia terjadi pada tanggal 10 Desember 1948, ketika Perserikatan Bangsa-
Bangsa mengadopsi Deklarasi Universal Hak Asasi Manusia (DUHAM), dimana terdapat beberapa pasal yang melindungi secara khusus hak-hak anak. (Lembaga Bantuan Hukum Jakarta, 2012:16)

Ada tiga prinsip dasar yang membentuk restorative justice, yaitu: (1) terjadi pemulihan kepada mereka yang menderita kerugian akibat kejahatan; (2) pelaku memiliki kesempatan untuk terlibat dalam pemulihan keadaan; dan pengadilan berperan untuk menjaga ketertiban umum dan masyarakat berperan untuk melestarikan perdamaian yang adil.

Dari prinsip dasar yang membentuk sistem restorative justice tersebut, maka dapat diketahui bahwa restorative justice akan memberikan timbal balik bagi pelaku maupun korban maupun orang-orang yang terlibat didalamnya. Di dalam restorative justice juga memugkinkan adanya pidana penjara apabila sanksi tersebut merupakan tuntutan korban dan dianggap bahwa dengan melakukan hukuman tersebut pelaku 
dianggap mempertanggungjawabkan tindakannya. Jadi sangat banyak variasi dari penyelesaian perkara melalui restorative justice didalam maupun diluar sistem peradilan. Pelaksanaan restorative justice dapat dilakukan apabila syarat-syarat terjadinya restorative justice terpenuhi, yaitu: (1) pengakuan atau pernyataan bersalah pelaku; (2) persetujuan dari pihak korban/keluarga dan adanya keinginan untuk memaafkan pelaku; (3) Dukungan komunitas setempat untuk melaksanakan penyelesaian secara musyawarah dan mufakat; (4) Kwalifikasi tindak pidana ringan; dan (5) Pelaku belum pernah dihukum.

Musyawarah Diversi adalah musyawarah antara para pihak yang melibatkan Anak dan orang tua/Walinya, korban dan/atau orang tua/Walinya, Pembimbing Kemasyarakatan, Pekerja Sosial Profesional, perwakilan masyarakat dan pihak-pihak yang terlibat lainnya) untuk mencapai kesepakatan Diversi melalui pendekatan Keadilan Restoratif.
Tahapan-tahapan yang dilakukan penyidik dalam penerapan pendekatan Restorative Justice di Polresta Surakarta: (a) Pertama pihak penyidik menerima laporan terlebih dahulu, (b) Setelah itu melakukan pemeriksaan saksi korban., (c) Setelah pemeriksaan saksi-saksi selesai, selanjutnya penyidik akan melakukan pemeriksaan terhadap tersangkanya, (d) Selanjutnya pihak penyidik melakukan penelitian ke BAPAS Surakarta, (e) Setelah mendapat rekomendasi dari BAPAS, Pihak penyidik PPA Polres Surakarta akan memanggil kedua belah pihak. Yakni keluarga korban dengan keluarga tersangka, LSM, Masyarakat sekitar untuk pelaksanaan Restorative Justice.

Diversi dan Restoratif Justice Sistem Peradilan Pidana Anak merupakan segala unsur sistem peradilan pidana yangterkait di dalam penanganan kasus-kasus ABH. Polisi, Kejaksaan dan Pengadilan serta pembimbing kemasyarakatan atau balai pemasyarakatan, Advokat atau pemberi bantuan, lembaga pembinaan 
khusus anak (LPKA), lembaga penempatan anak sementara (LPAS) dan lembaga pembinaan kesejahteraan sosial (LPKS) sebagai institusi atau lembaga yang menangani $\mathrm{ABH}$ mulai dari anak bersentuhan dengan sistem peradilan, menentukan aoakah anak akan dibebaskan atau diproses ke pengadilan anak hingga tahapan ketika anak akan ditempatkandalam pilihan-pilihan, mulai dari dibebaskan sampai dimasukan dalam institusi peenghukuman dalam koridor keadilan restoratif. Hal itu selaras dengan :

1. Deklarasi PBB tahun 2000 tentang Prinsip-prinsip pokok tentang Penggunaan Program-program Keadilan Restoratif dalam Permasalahan-permasalahan Pidana (United Nations Declaration on The Basic Principles on the Use of Restoratif Justice Programmes in Criminal Matters).

2. Deklarasi Wina tentang Tindak Pidana dan keadilan (Vienna Declaration on Crime and Justice : "Meeting the challenges of Twenty
First Century") butir 27-28 tentang keadilan restratif.

3. Kongres PBB ke-XI di Bangkok tahun 2005 tentang pencegahan kejahatan dan peradilan pidana (Eleventh and Criminal Justice) pada butir 32 : "Persekutuan Strategis dalm Pencegahan tindak pidana dan peradilan pidana (Synergies and Responses : Strategic Alliances in crime Prevention and Criminal Justice)”.

Selanjutnya diatur dalam UU 11 Tahun 2012 dan PERMA 4 Tahun 2014 Berdasarkan UU SPPA Diversi adalah pengalihan penyelesaian perkara anak dari proses peradilan pidana ke proses di luar peradlan pidana, yang bertujuan untuk :

1. Mencapai perdamaian antara korban dan anak;

2. Menyelesaikan perkara anak di luar proses peradilan;

3. Menghindarkan anak dari perampasan kemerdekaan;

4. Mendorong masyarakat untuk berpartisipasi; dan

5. Menanamkan rasa tanggung jawab kepada anak. 
Dalam PERMA 4 tahun 2014 dijelaskan bahwa Diversi dberlakukan terhadap anak yang telah berumur 12 tahun tetapi belum berumur 18 tahun atau telah berumur 12 tahun meskipun pernah kawin tetapi belum berumur 18 tahun, yang diduga melakukan tindak pidana (pasal 2). PERMA ini juga mengatur tahapan musyawarah diversi, dimana fasilitator yang ditunjuk Ketua Pengadilan wajib memberikan kesempatan pada :

1. Anak untuk didengar keterangan perihal dakwaan.

2. Orang tua/wali untuk menyampaikan hal-hal yang berkaitan dengan perbuatan anak dan bentuk penyelesaian yang diharapkan.

3. Korban/Anak Korban/Orang Tua/Wali untuk memberikan tanggapan dan bentuk penyelesaian yang diharapkan.

Bila dipandang perlu, fasilitator diversi dapat memanggil perwakilan masyarakat maupun pihak lain untuk memberikan informasi untuk mendukung penyelesaian dan/atau dapat melakukan pertemuan terpisah
(Kaukus), Kaukus adalah pertemuan terpisah antara Fasilitator Diversi dengan salah satu pihak yang diketahui oleh pihak lainnya. (www.mahkamahagung.go.id)

Dengan lahirnya UndangUndang Nomor 11 Tahun 2012 tentang Sistem Peradilan Anak pada Pasal 6 tentang Diversi, akan memberikan suatu pemahaman baru yang dapat menjadi jalan keluar bagi masalah kejahatan anak di Indonesia, dimana aparat penegak hukum dituntut lebih bijak dalam memahami dan memaknai kasus-kasus anak nakal. Salah satu solusi yang dapat digunakan adalah dengan pelaksanaan diversi (pengalihan) atau dengan Restorative Justice, dimana Polisi adalah garda terdepan dalam pelaksanaannya melalui wewenang diskresinya.(ejurnal.bunghatta.ac.id)

Salah satu upaya pemerintah dalam melakukan pencegahan dan penanggulangan kenakalan yaitu dengan menyelenggarakan sistem peradilan pidana anak (juvenile justice system) melalui UU No. 11 Tahun 2012 tentang Sistem Peradilan 
Pidana Anak yang menggantikan UU No. 3 Tahun 1997 tentang Pengadilan Anak yang dilakukan dengan tujuan agar dapat terwujud peradilan yang berar-benar menjamin perlindungan kepentingan terbaik terhadap anak yang berhadapan dengan hukum sebagai penerus bangsa. (Nandang Sambas, 2010:60)

Pelaksanaan Restorative Justice dapat dilakukan melalui kegiatankegiatan seperti restitusi; mediasi korban dengan pelaku/pelanggar; musyawarah kelompok keluarga; pelayanan di masyarakat yang bersifat pemulihan baik bagi korban maupun pelaku; pelayanan korban; restorasi masyarakat; atau denda restroatif. Restorative Justice merupakan cara penjatuhan sanksi terhadap anak nakal dengan memberikan hak kepada korban untuk ikut serta secara aktif dalam proses peradilan. Indikator pencapaian tujuan penjatuhan sanksi dalam penerapan Restorative Justice dapat dilihat dari apakah korban telah direstorasi, kepuasan korban besarnya ganti rugi, kesadaran pelaku atas perbuatannya, jumlah kesepakatan perbaikan yang dibuat, kualitas pelayanan kerja dan keseluruhan proses yang terjadi. Program diversi dapat menjadi bentuk Restorative Justice jika:

a. Mendorong anak untuk bertanggung jawab atas perbuatannya;

b. Memberikan kesempatan bagi anak untuk mengganti kesalahan yang dilakukan dengan berbuat kebaikan bagi si korban.

c. Memberikan kesempatan bagi si korban untuk ikut serta dalam proses;

d. Memberikan kesempatan bagi anak untuk dapat mempertahankan hubungan dengan keluarga;

e. Memberikan kesempatan bagi rekonsiliasi dan penyembuhan dalam masyarakat yang dirugikan oleh tindak pidana.

Apabila demi kepentingan umum, maka proses hukum harus dilakukan. Diversi dapat dimplementasikan dalam beberapa bentuk. Secara garis besar, terdapat tiga bentuk diversi, yaitu:

a. Diversi dalam bentuk peringatan, ini akan diberikan kepada polisi untuk 
pelanggaran ringan. Sebagai bagian dari peringatan, si pelaku akan meminta maaf pada korban. Peringatan seperti ini telah sering dilakukan.

b. Diversi informal, yang diterapkan terhadap pelanggaran ringan di mana dirasakan kurang pantas jika hanya sekedar member peringatan kepada pelaku, dan kepada pelaku diperlukan rencana intervensi yang lebih komperhensif. Pihak korban harus diajak untuk memastikan pandangannya tentang diversi informal dan apa yang mereka inginkan di dalam rencana tersebut. Diversi informal harus berdampak positif kepada korban, keluarga, dan anak. Yaitu dipastikan bahwa pelaku anak akan cocok diberikan diversi informal. Rencana diversi informal ini, anak akan bertanggung jawab, mengakui kebutuhan - kebutuhan korban dan anak, dan kalau mungkin orang tua dimintai pertanggungjawaban atas kejadian tersebut.

c. Diversi formal, yang dilakukan jika diversi informal tidak dapat dilakukan, tetapi tidak memerlukan intervensi pengadilan. Beberapa korban akan merasa perlu mengatakan pada anak betapa marah dan terlukanya mereka, atau mereka ingin mendengarkannya langsung dari anak. Karena permasalahannya muncul dari dalam keluarga anak, maka ada baiknya ada anggota keluarga lainnya yang hadir untuk mendiskusikan dan menyusun rencana diversi yang baik untuk semua pihak yang terkena dampak dari perbuatan itu.

Proses diversi fomal di mana pelaku dan korban bertatap muka, secara internasional ini disebut sebagai "Restoratif Justice". Ide diversi secara konseptual akan lebih sesuai dalam melakukan upaya penindakan dan penjatuhan sanksi terhadap anak nakal dalam kerangka perlindungan anak terhadap stigma (cap jahat) ketika seorang anak melakukan perbuatan kejahatan atau pelanggaran hukum. Namun demikian dalam system peradilan pidana anak di Indonesia, ide diversi 
tersebut tidak mudah untuk mengenai lokasi pelaksanaan diimplementasikan.

rehabilitasi anak.

2. Kendala penerapan diversi terhadap anak yang berhadapan dengan hukum Peraturan Mahkamah Agung Nomor 4 Tahun 2014 Tentang Pedoman Pelaksanaan Diversi Dalam Sistem Peradilan Pidana Anak

Beberapa kendala dalam penerapan PERMA Nomor 4 tahun 2014 Tentang Pedoman Pelaksanaan Diversi Dalam Sistem Peradilan Pidana Anak

1. Belum adanya Peraturan Pelaksanaan Diversi. Agar peraturan Mahkamah Agung berlaku dan memiliki kekuatan mengikat bagi para pihak di peradilan pidana anak, maka dibutuhkan peraturan pemerintah sebagai aturan pelaksanaannya, selama belum tersedianya (Peraturan Pelaksana) PP dalam melaksanakan Perma No. 4 tahun 2014 maka PERMA ini belum dapat sepenuhnya dilaksanakan. Perma membutuhkan PP dikarenakan ada beberapa point penting yang seharusnya diatur dalam PP tersebut, salah satunya adalah
2. PERMA diversi hanya berlaku bagi diversi di pengadilan, padahal di dalam pasal 7 ayat (1) Undangundang Sistem Peradilan Pidana Anak mengamanatkan diversi diberlakukan pada setiap tingkat peradilan baik di tingkat kepolisian maupun kejaksaan.

3. Belum diaturnya diversi pada tindak pidana "Victimless" belum diaturnya diversi bagi tindak pidana yang sifatnya victimless atau tidak memiliki korban sebagai pihak terkait. Padahal, hal yang terjadi dilapangan adalah, banyaknya anak yang berhadapan dengan hukum melakukan suatu tindak pidana yang tidak memiliki korban namun sangat membahayakan dirinya sendiri atau dengan kata lain, dirinya sendirilah yang menjadi korban dari perbuatannya. Dalam hal ini kasus pemakaian obat-obatan terlarang atau narkoba diberbagai tingkat usia sekolah baik dari tingkat sekolah dasar sampai menengah atas. 
4. Aparat penegak hukum dalam hal ini kepolisian diberikan mandat oleh undang-undang untuk menegakkan, di sisi lain Polri juga diberi ruang untuk melakukan tindakan diskresi kepolisian berdasarkan penilaiannya sendiri untuk kepentingan umum. Dalam menangani kasus yang melibatkan anak sebagai pelaku pidana diskresi kepolisian diperlukan untuk menjembatani koonsep keadilan restoratif juctice, namun pada kenyataannya lebih banyak polisi yang masih mempunyai paradigma legalistik, kaku dan kurangnya pemahaman tentang penanganan anak yang berhadapan dengan hukum, serta masih memiliki pola pikir bahwa pemberian sanksi pidana lebih adil daripada penyelesaian secara damai.

5. Proses Diversi. Diversi seharusnya sudah dilakukan sejak tahap penyidikan agar tidak diteruskan ketahap penentutan. Namun, realita yang terjadi dilapangan adalah kasuskasus hukum yang menimpaanak ditangani melalui proses hukum. Hal ini menyulitkan kejaksaaan dalam penerapan diversi karena bekerjanya subsistem kejaksaaan tidak terlepas dari BAP dan alat bukti yang disampaikan oleh subsistem kepolisian. Ditambah laagi, tidak ditemukan dalam pengaturan kewenangan kejaksaanuntuk melakukan tindakan lain seperti faasilitator atau mediator untuk menyelesaikan perkara.

6. Faktor Masyarakat, masyarakat mempengaruhi suatu penegak hukum penegak hukum, hal ini dikarenakan penegak hukum itu berasal dari keinginan masyarakat dan bertujuan untuk mencari kedamaian ditengahtengah masyarakat. Pada penerapan diversi dalam merespon suatu tindak pidana disamping korban dan pelaku itu sendiri masih kentalnya paradigma di masyarakat yang mengharuskan setiap perbuatan pidana yang timbul harus dijatuhi hukuman pidana dan adanya respon negatif dari masyarakat terhadap upaya-upaya penyelesaian melauli jalan perdamaian dan kekeluargaan yang dilakukan oleh aparat penegak hukum. 
7. Faktor sarana dan prasarana, bersama dalam penyelesaian maslah ketidakmampuan pemerintah dalam menyediakan sarana dan prasarana yang memadai untuk melindungi hakhak anak yang melakukan tindak pidana. Contohnya adalah jumlah Bapas berbanding terbalik dengan juumlah $\mathrm{ABH}$, artinya jumlah $\mathrm{ABH}$ yang besar tidak diikuti oleh jumllah Bapas yang memadai di berbagai daerah di Indonesia, selain itu dalam satu bapas tenaga atau sumber daya manusia yang ada didalamnya hanya berjumlah tiga puluh orang, sementara $\mathrm{ABH}$ yang harus ditangani berjumlah ribuan.

8. Anggaran yang diperlukan untuk melaksanakan diversi tidak murah. Seperti dalam hal mempertemukan para pidak dan transportasi yang dibutuhkan. Sebagaimana diketahui diversi sebagai salah satu contohpenerapan restorative juctice dijalankan melalui sebuah proses, yakni proses dimana korban dan pelaku dan/atau orang lain atau anggota yang terkena dampak kejahatan secara aktif berpartisipasi

yang timbul karena kejahatan.

Selain beberapa kendala atau hambatan di atas dalam melakukan diversi kepada anak yang berhadapan dengan hukum, beberapa hal juga yang menjadi kendala yaitu:

a. Hambatan Secara Internal

Secara internal juga mengalami hambatan yaitu pemahaman yang belum mendalam terhadap isi dari Perma Nomor 4 Tahun 2014 tentang Pedoman Pelaksanaan Diversi dalam Sistem Peradilan Pidana Anak, sehingga hal tersebut akan menjadi kesulitan.

Uraian tersebut bila dianalisis dengan teori sistem hukum yaitu pada budaya hukum (legal culture) merupakan sikap manusia terhadap hukum dan sistem hukum. Sikap masyarakat ini meliputi kepercayaan, nilai-nilai, ide-ide serta harapan masyarakat terhadap hukum dan sistem hukum. Budaya hukum juga merupakan kekuatan sosial yang menentukan bagaimana hukum disalahgunakan. Budaya hukum (legal culture) mempunyai peranan 
yang besar dalam sistem hukum, tanpa budaya hukum (legal culture) maka sistem hukum (legal system) akan kehilangan kekuatannnya, seperti ikan mati yang terdampar di keranjangnya, bukan ikan hidup yang berenang di lautan (without legal culture, the legal system is meet-as dead fish lying in a basket, not a living fish swimming in its sea). Maka dapat dikatakan bahwa pemahaman masih menjadi kendala, maka dari itu lahirlah Perma ini sehingga menjadi acuan bagi para hakim atau fasilitator Diversi di Pengadilan seluruh Indonesia.

b. Hambatan Eksternal

$$
\text { Secara eksternal juga }
$$
mengalami hambatan yaitu :

1. Pemahaman masyarakat dan aparat penegak hukum lainnya terhadap Diversi masihlah kurang.

2. Peran masyarakat masih minim terutama dari masyarakat yang menjadi korban.

3. Kerjasama instansi lain terkait penerapan Diversi belum berjalan dengan baik.

c. Pelaku adalah Korban
Pelaku kenakalan anak adalah korban. Memang, mungkin terbukti melakukan tindak kenakalan, anak melanggar hukum positif, kelakuannya mungkin akan mengganggu tertib sosial karena kenakalannya membuat marah publik, dan karena ulahnya ada pihak yang dirugikan, bahakn karena kenakalannya akan mendatangkan kematian dan siksa orang lain. Namun, apa pun alasannya, sesungguhnya dia adalah korban.(Hadi Supeno, 2010:92)

Kekerasan telah menjadi spiral yang terkonstruksi secara sosial. Para pahlawan adalah mereka yang pernah berperang. Karya-karya sastra besar adalah karya yang menceritakan tentang kekerasan dan perang. (Hadi Supeno, 2008:99) Menjadi masuk akal ketika Franz Magnis Suseno menyatakan bahwa kekerasan sudah merupakan kenyataan dalam kehidupan bangsa Indonesia. Ini mengindikasikan bahwa ada lingkungan sosial yang keras, yang mempola lahirnya individu berwatak 
keras dengan segala karakteristiknya, pemenuhan hak-haknya seta termasuk anak. dilindungi dari perlakuan salah, Dengan pemahaman yang eksploitasi, kekerasan, dan komprehensif nyatalah bahwa posisi diskriminasi. anak, walaupun dia sebagai pelaku e. Prinsip Adil dan Setara (offender) tindak kenakalan, Prinsip ini mengharukan aparat sesungguhnya dia adalah korban (victim). Korban dari pelaku orang dewasa, kebijakan pemerintah dan Negara, serta lingkungan sosial budaya di sekolah dan masyarakat yang dibangun orang-orang tua. Karena pelaku adalah korban menjadi tidak adil manakala dia harus memperoleh hukuman dari sistem peradilan yang semata-mata memojokkannya.

d. Tidak Mengganggu Tumbuh Kembang Anak

Penanganan anak yang berkonflik dengan hukum tidak boleh mengganggu tumbuh kembang anak. Pada paragraph terdahulu sudah dijelaskan bahwa anak bukanlah manusia dewasa dalam bentuk mini, tetapi sosok pribadi otonom yang sedang tumbuh dan berkambang. Dia akan mencapai pertumbuhan (fisik) optimal apabila memperoleh jaminan penegak hukum yang menangani kasus-kasus anak berhadapan dengan hukum memperlakukan anak-anak tanpa membedakan status sosial, asal usul, agama, ras, dan sebagainya.

\section{PENUTUP}

\section{Kesimpulan}

1. Penerapan diversi terhadap anak baik pada tingkat Penyidikan, Penuntutan dan Peradilan dapat dilaksanakan selama memenuhi persyaratan, sebagaimana diatus dalam Pasal 7 angka 2 Undang-Undang Sistem Peradilan Pidana Anak dan sesuai dengan Perma Nomor 4 Tahun 2014 tentang Pedoman Pelaksanaan Diversi Dalam Sistem Peradilan Pidana Anak yang menyatakan bahwa diversi dapat dilaksanakan dalam hal tindak pidana yang dilakukan dengan diancam pidana penjara di bawah 7 (tujuh) tahun dan bukan merupakan pengulangan tindak pidana. 
2. Kendala Implementasi Diversi dalam penanganan tindak pidana yang dilakukan oleh anak, Pemahaman masyarakat dan aparat penegak hukum lainnya terhadap Diversi masihlah kurang, Peran masyarakat masih minim terutama dari masyarakat yang menjadi korban. Serta kerjasama instansi lain terkait penerapan Diversi belum berjalan dengan baik.

\section{Saran}

1. 1. Diperlukanya seluruh Ketentuan penunjang yang telah diamanatkan oleh Undang-Undang Nomor 11 tahun 2012 dan Peraturan Mahkamah Agung Nomor 4 Tahun 2014 sebagai ketentuan pelaksana atas penanganan tindak pidana yang dilakukan oleh anak.

2. 2. Bahwa selain penegasan terhadap peraturan penunjang Undang-Undang Nomor 11 tahun 2012 dan Peraturan Mahkamah Agung Nomor 4 Tahun 2014, sebaiknya diadakan pelatihan bersama terhadap pihak-pihak yang terlibat dalam Pelaksanaan UndangUndang Nomor 11 tahun 2012 dan Peraturan Mahkamah Agung Nomor
4 Tahun 2014, serta pihak-pihak pelaksana Diversi anak pada umumnya.

\section{DAFTAR PUSTAKA}

\section{A. Buku :}

Dey Ravena dan Kristian. Kebijakan Kriminal (Criminal Policy). Kencana. Jakarta. 2017

Hadi Supeno "Konstruksi Kekerasan Terhadap Anak," majalah Warta KPAI, Edisi II, 2008.

Hadi Supeno, Kriminalisasi Anak, Tawaran Gagasan Radikal Peradilan Anak Tanpa Pemidanaan, (Jakarta: PT. Gramedia, 2010).

Lembaga Bantuan Hukum Jakarta. Mengawal Perlindungan Anak Berhadapan Dengan Hukum. Jakarta. Lembaga Bantuan Hukum. 2012.

Nandang, Sambas. Pembaharuan Sistem Pemidanaan Anak di Indonesia, Yogyakarta: Graha Ilmu, 2010.

Setya Wahyudi. Implementasi Ide Diversi Dalam Pembangunan Sistem Peradilan Pidana Anak di Indonesia.. Genta Publishing. Yogyakarta. 2011.

Supriyadi W. Eddyono, Pengantar Konvensi Hak Anak, (Jakarta: ELSAM, 2005.

\section{B. Jurnal :}

(M. R. Ghoni, and P. Pujiyono, Perlindungan Hukum Terhadap Anak yang Berhadapan dengan Hukum Melalui Implementasi Diversi di Indonesia, Jurnal 
Pembangunan Hukum Indonesia, Vol. 2, No. 3, pp. 331-342, Aug. 2020. https://doi.org/10.14710/j phi.v2i3.331-342).

ejurnal.bunghatta.ac.id.

C. Peraturan Perundang-Undangan :

Undang-Undang Nomor 2 Tahun 2002 tentang Kepolisian.

\section{Internet dan Data Lapangan:}

Data dari Satuan Reserse Kriminal Kabupaten Cirebon

DS. Dewi, "Restorative Justice, Diversionary Schemes and Special Childrens's Courts in Indonesia",

http://www.kemlu.go.id/canb erra/Lists/LembarInformasi/

Attachments/61/Restorative\%

20Justice, \%20Diversionary

$\% 20$ Schemes\%20and\%20Spe

cial\%20Children $\%$ E2\%80\%

99s\%20Courts\%20in\%20Ind

onesia.pdf, diakses 2

November 2019.

www.mahkamahagung.go.id

diakses 2 November 2019
Undang-Undang Nomor 23 Tahun

2002

tentang

Perlindungan Anak

Undang-Undang Nomor 11 Tahun 2012 tentang Sistem Peradilan Pidana Anak

Perma Nomor 4 Tahun 2014 Tahun 2014 Tentang pedoman pelaksanaan diversi dalam sistem peradilan pidana anak 